\title{
KAMOLONE FROM THE ROOTS OF
}

\section{Ferula kopetdaghensis}

\author{
Kh. M. Kamilov and G. K. Nikonov
}

UDC 547.992:547.913.5:668.5

Continuing a study of the coumarins of the above-named plant, from the ethereal fraction after the elimination of the galbanic acid [1] we have isolated another lactone, with the composition $\mathrm{C}_{24} \mathrm{H}_{32} \mathrm{O}_{4}, \mathrm{M}^{+}$ $382, \mathrm{mp} 189-190^{\circ} \mathrm{C}$ (methanol), $[\alpha]_{18}^{18}+63^{\circ}$ (c 1.0; chloroform), $\mathrm{R} f 0.21$ [petroleum ether-ethyl acetate (5:1) system]. From its chemical composition and $U V$ spectrum [244, 255, and $327 \mathrm{~nm}(\log \varepsilon 3.64,3.38$, and 4.29 , respectively) ] it belongs to the 7-hydroxycoumarin derivatives. Its IR spectrum contains absorption bands at $\left(\mathrm{cm}^{-1}\right): 1733$ (carbonyl of an $\alpha$-pyrone), 1617, 1562 (aromatic nucleus), 2990, 2965, 2940, and 1380-1360 (C-methyl groups), and 1713 (carbonyl group of a saturated ketone). Acid hydrolysis of the lactone gave umbelliferone $\mathrm{C}_{9} \mathrm{H}_{6} \mathrm{O}_{3}$ with $\mathrm{mp} 229-231^{\circ} \mathrm{C}$ (from water), which was identified by the absence of a depression of the melting point in a mixture with 7-hydroxycoumarin.

Consequently, the coumarin isolated is an ether of umbelliferone and a sesquiterpene ketone with the composition $\mathrm{C}_{15} \mathrm{H}_{26} \mathrm{O}_{2}$. The presence of an oxo group in it was confirmed by the formation of a 2,4-dinitrophenylhydrazone with $\mathrm{mp} 247-248^{\circ} \mathrm{C}$. From the compositions and melting points of the substance and its phenylhydrazone, and also from its IR and PMR spectra, it was identified as kamolone, isolated previously from Ferula penninervis Fgl. et Schmalh. [2, 3]. Thus, Ferula kopetdaghensis is the second plant in which kamolone has been detected.

\section{TE RA TURE CITED}

1. Kh. M. Kamilov and G. K. Nikonov, Khim. Prirodn. Soedin., 114 (1972).

2. N. E. Ermatov, A. I. Ban'kovskii, and M. E. Perel'son, Khim. Pri rodn. Soedin., 158 (1966).

3. N. E. Ermatov, A. I. Ban'kovski, M. E. Perel'son, G. P. Syrova, and Yu. N. Sheinker, Khim. Pri rodn. Soedin., 79 (1969).

Order of the Red Banner of Labor Institute of the Chemistry of Plant Substances, Academy of Sciences of the Uzbek SSR. Translated from Khimiya Pri rodnykh Soedinenii, No. 1, pp. 85-86, JanuaryFebruary, 1974. Original article submitted June 12, 1973.

(C) 1975 Plenum Publishing Corporation, 227 West 17th Street, New York, N.Y. 10011. No part of this publication may be reproduced, stored in a retrieval system, or transmitted, in any form or by any means, electronic, mechanical, photocopying, microfilming, recording or otherwise, without written permission of the publisher. A copy of this article is available from the publisher for $\$ 15.00$. 